\title{
Towards a Model of Public Relations for Public Organizations of Afghanistan
}

\author{
Farid Ahamd Monib ${ }^{1,2}$, Jamaluddin Qanet ${ }^{1,2}$, Redwanullah Abdi ${ }^{1}$ \\ ${ }^{1}$ Economy Faculty, Dunya University, Kabul, Afghanistan \\ ${ }^{2}$ Faculty of Journalism, Al-Beroni University, Kapisa, Afghanistan \\ Email: *afaridmonib@gmail.com, prof.faridmonib@au.edu.af
}

How to cite this paper: Monib, F. A., Qanet, J., \& Abdi, R. (2021). Towards a Model of Public Relations for Public Organizations of Afghanistan. Open Journal of Social Sciences, 9, 214-230. https://doi.org/10.4236/jss.2021.97015

Received: June 14, 2021

Accepted: July 17, 2021

Published: July 20, 2021

Copyright (c) 2021 by author(s) and Scientific Research Publishing Inc. This work is licensed under the Creative Commons Attribution International License (CC BY 4.0).

http://creativecommons.org/licenses/by/4.0/ (c) (i) Open Access

\begin{abstract}
This study compares public relation's models for Afghan public organizations of public relations activities. Such models are based on the tactics that public relations choose to achieve its goals and the goals that it designs its messages and programs to achieve. The value of correlation is based on standard coefficients for the value index equal to 966 , for the interaction index equal to 940 , for the instrumental and technology index equal to 693 and finally for the management index equal to 925 . Interestingly, the highest correlation is seen in the value index. The model of measuring the good public relations of public organizations in Afghanistan based on standard coefficients and general indicators of the conceptual model has relation with each other. The results were almost identical in the views of professors, staff, experts, and quantitative findings show that there was a value index at a high level of acceptance.
\end{abstract}

\section{Keywords}

Public Relations, Public Information Model, Advertising, Unequal and Equal Bilateral, Afghanistan

\section{Introduction}

Public Relations are a profession dedicated to the effective use of communication (Hobbs \& Mann, n.d.). The categorization of communication in organizations is necessary and at the same time, it is sensitive and non-negligible due to the breadth of their field of activity, both within the organization and outside the organization, and even in the international dimension. This relationship, which is referred to as "public relations", is one of the most important and valuable factors in the fate of any institution and group (Mackey, 2003; Bhutan 
\& Hazleton, 2008: pp. 191-192). Public relations, according to the need based on the development of information in society and in interaction with other systems and subsystems, have played a prominent role in the production and use of information for development of advanced systems of communication sciences (Hobbs \& Mann, n.d.), and have moved towards expanding trust and partnership between organizations and the public and ultimately the audience (Rex, 2015).

In Afghanistan, public relations as a subsystem in the field of public organizations, like other organizational units and institutions, almost after the 2001s and the establishment of a new system and the influx of military forces of the international community, found a special place. Previously, public relations activities and tasks were carried out under the name of press activities. However, little attention has been paid to the development and expansion of this field, the effectiveness of public relations functions, especially the speech of public organizations, at the level of efficiency and information is evident.

However, due to the human nature of this science, it plays different roles in different positions and conditions, its main activity can be evaluated in two distinguishable roles, namely, "internal and external organizational communication", which is more prominent and important than other roles. Public relations, in addition to drawing the general lines of the organization's communication in both internal and external dimensions, are to be able to identify the facilities and conditions of the external environment and connect them with the facilities within the organization. It also facilitates the execution of orders within the organization to ultimately establish the organization's relationship with the outside world properly. Obviously, the first step in planning and drawing the communication lines of an organization or institution is to know the environment and the relevant organization, and the purpose of this knowledge is to identify and examine the strengths and weaknesses. In addition, familiarity with public relations with the capabilities and shortcomings of the organization can outline the main course of its activities and prevent wasting material resources and time to address other unnecessary issues.

Familiarity with public relations with the capabilities and shortcomings of the organization can outline the main course of its activities and prevent wasting material resources and time to address other unnecessary issues. Given the various perspectives and applications of public relations, this dynamic discipline is governed by the premise that the goal of public relations is to influence people's behavior under the pretext of preserving the appearance, if not real, of influential groups and organizations. Worldviews include this premise and its successors can be described by the four public relations models introduced in 1948. The four models of public relations represent the values, goals and behaviors that organizations apply in their public relations work. These models have the same complete introduction or complete competition and simple representation in other sciences, they are presented in a simple way. 
In this study, the researcher seeks to propose an appropriate model to public organizations in Afghanistan, this occurs comparing different models of public relations. To achieve this goal, the question that arises is "what is the optimal model of public relations for the management of the activities in public organizations? Based on which indicators the function of public relation subsystem is measured?

\section{Literature Review}

The term public relations, the English translation of the word (Public Relations), was first used in the United States Railroad Association (Rex, 2015). In fact, public relations are the management of favorable relations between the organization and various audiences, management of the departments or the technique and knowledge of the administration and the overall relations of an organization and various groups (Mackey, 2003; Grunig, n.d.). Public relations in government ministries aim at achieving mutual understanding between their agencies and publics by following a strategic public relations process (Van Heerden, 2004; Maina \& Mberia. 2014). According to Edward Bernice, giving information to the people and making persuasive efforts to change the attitudes and behavior of the people and trying to solidify the attitudes and actions of an organization with its audience and in return the attitudes and actions of the audience with the organization Knows the major activities of public relations. In another definition of Grunig and Hunt, public relations are the management of the relationship between an organization and its audience (Bahramian, 2011; Van Heerden, 2004; Rhee, 2004). In other words, people in public relations who follow a symmetrical "two-way" pattern are not completely altruistic; Rather, they want to defend the interests of their employers (Rex, 2015; Grunig, 1994: p. 18). Optimal public relations in today's world is an institution that relies on knowledge management, information technology management, electronic public relations and process management and creating a process-oriented attitude in organizational performance to affect the fluid, moving, lively and dynamic public opinion of society (Van Heerden, 2004; Maina \& Mberia. 2014; Rhee, 2004). Put. This public relation is in fact able to use all the new communication tools and technologies and use the achievements of management science in intra-organizational and extra-organizational communication and its activities (Grunig, 2006; Mackey, 2003; Soltanifar \& Noorabadi, 2015). In a desirable and efficient public relations structure, communication must be carefully measured and evaluated using well-known scientific methods, the audience's reaction to the messages, and the imposition of messages on people or disregard for reactions (Taylor \& Botan, n.d.). People should be avoided in the face of messages that both lead to a lack of participation (Hobbs \& Mann, n.d.; Rhee, 2004; Shukri Khaneghah, 2015: pp. 36-35).

However, the history of communications and public relations track back to the lifespan of human groups and human governments (Van Heerden, 2004); But in the discussion of the "new public relations" the dramatic changes that 
took place after the Industrial Revolution in Europe and the rapid growth of factories that led to the employment of manpower on a large scale (Hobbs \& Mann, n.d.; Grunig, 2006; Rhee, 2004). The use of this huge force required the organization of principled organizational communications and the sale of services and goods required the use of the principles of audience and advertising (Van Heerden, 2004; Grunig, n.d.).

Ivy Ledbetter Lee, a Princeton University graduate and New York World reporter, was founded in New York City. Later, with the efforts of people like "Edward Bernice", training courses in this field were held in American universities and numerous articles and books were written in this field (Ng, 2003; Hobbs \& Mann, n.d.). In 1949, with the formation of the International Association of Public Relations and the membership of many countries, the scientific activities of public relations took on a global dimension (Maina \& Mberia, 2014; Rex, 2015; Bahramian, 2011).

(J. E. Grunig) and (T. Hunt) described four public relations models, he introduced in 1948 (Maina \& Mberia. 2014). The four public relations models represent the values, goals, and behaviors that organizations apply to their public relations work (Taylor \& Botan, n.d.). These models are presented in the same order or complete competition and are simply represented in other principles (Ng, 2003). These models are: Press and Advertising Office, General Information, Balanced and Balanced (Mackey, 2003; Grunig, 2006; Bhutan \& Hazleton, 2008: p. 27; Kazempour, Ashrafi Rizi, \& Abdollahi, 2013: p. $57)$.

The Advertising and Press Office is the public relations office of advertising that tries to attract the attention of the media in every possible way (Van Heerden, 2004). The history of the advertising model dates back to the late 19th century. In this model, the main goal is advertising. According to this model, public relations act as a representative of the press in the organization and seek to feed the press by preparing various news items (Mackey, 2003; Kazempour, Ashrafi Rizi, \& Abdollahi, 2013: p. 58). In this model, the recipient is the one who must accept a particular idea, and as Grunig and Hunt have pointed out, in this model, complete truth is not necessary. It seems that the constant distrust of this public relations is largely due to the applicability of this model $(\mathrm{Ng}$, 2003; Grunig, 2006). The advertising model creates a kind of public relations that has emerged for the sale of products and services (Cabot, 2012; Grunig, n.d.). According to August Kent, this is the founding stage (Taylor \& Botan, n.d.). The issues of the organization are told regardless of public opinion. This course is called acceptance engineering because the introduction is for admission only. This model is linear, from top to bottom (Mackey, 2003; Monib, 2017: p. 60).

The public information model defines the public relations approach used by resident journalists, who usually report what is true about the organization; often they do not voluntarily spread negative information. Both of these examples 
are one-way models that interns follow by giving organization information to groups; but they do not seek information from people through research or informal methods (Van Heerden, 2004; Maina \& Mberia. 2014). The aim of this model is to disseminate information that is not necessarily persuasive. Unlike the first model here, public relations report exactly what is happening in the organization to others (Cabot, 2012). In this model, the most important task of public relations is to disseminate information and pay attention to the authenticity of the content of messages and public relations programs. Despite the having more logical flow of communication with the audience, communication methods are still limited and one-way and research is not given the necessary importance (Kazempour, Ashrafi Rizi, \& Abdollahi, 2013: p. 59). According to this model, a journalist is the one who is hired by an organization to report what is happening inside the organization to the masses. An example of the application of public relations in following this model. According to this model, $50 \%$ of most public relations organizations use this model. IV Liberd is one of the prominent figures of this period (Hobbs \& Mann, n.d.; Cabot, 2012; Monib, 2017: p. 62).

Both organizational legitimacy and public relations offer models for exploring relationships between an organization and its environment. These relationships are built around two key elements, stakeholders and communication, the importance of which are first discussed and then integrated to develop a model of organizational legitimacy in the practice of public relations (Patel et al., 2005). The heterogeneous or organization-centric two-way model that emerged in the 1920s is more dynamic than previous models (Patel et al., 2005). In this model, information flows in two directions, both to and from the public. The presence of feedback in this model is a new thing; but the mere presence of feedback does not mean that power is evenly distributed between the sender and receiver (Van Heerden, 2004; Ng, 2003). Communication in this model, the initiative is still under the power of the organization and the goal of communication is persuasion and also changes attitudes and behaviour (Cabot, 2012). Impacts are disproportionate; because desirable behavioural change benefits the organization, not the groups, although many interns believe that influential groups also benefit. As a result, the heterogeneous two-way model is an example of many new and complicated current PR practices. Nevertheless, it describes a model that is consistent with the dominant system of thought that Bernice and others completed decades ago (Van Heerden, 2004). In this model, attention to the recipients of the messengers is replaced and the feedback of the messages is considered; But attention to the feedback system is only for the benefit of the organization and the interests of the audience are not important, in other words, public relations only seeks the consent of the audience and tries to change the ideas and behaviors of social groups (Cabot, 2012; Kazempour, Ashrafi Rizzi, \& Abdollahi, 2013 , p. 60). Scientific persuasion takes the audience seriously and persuasion forms the most sublime form of communication (Beverly, 2013; Bhutan \& Hazleton, 2008: pp. 43-44). 
A cohesive, audience-centric two-way model developed during the 1960s and 1970s, and PR practitioners gradually and cautiously embraced it as a communication strategy (Beverly, 2013). While the hallmark of other public relations models is one-of-a-kind communication, the two-way peer-to-peer model involves the idea of dialogue (Bentley, 2012; Taylor \& Botan, n.d.). As with dialogue, itself, no single definition of dialogic pedagogy exists. Dialogic pedagogy has been used to identify a set of classroom techniques, as well as a fundamental approach to the construction of knowledge (Bentley, 2012). This practice leads the management of the organization to exchange ideas and opinions with other groups and possibly causes the management and their colleagues to be both affected and to adjust their attitudes and behaviors. The connection in this model is completely two-way. The purpose of this model is to create understanding (Ng, 2003; Beverly, 2013).

The main feature of this model is to give an equal role to public relations towards the audience and to avoid adopting a domineering strategy in communication with him. In this model, achieving understanding with the audience, replaces persuasion, and by taking the initiative out of the power of the organization and thus giving an equal role to the audience, the vertical relationship of the organization-audience replaces the group-group relationship (Bentley, 2012; Van Heerden, 2004). In fact, the organization and the audience are presented as two groups in the communication process of public relations. Attention to the ethical aspects of public relations still finds its place in public relations activities, although its examples are not yet clear (Taylor \& Botan, n.d.; Beverly, 2013; Sefidi, 2015: pp. 61-65; Kazempour, Ashrafi Rizi, \& Abdollahi, 2013: p. 63; Bhutan \& Hazleton, 2008: pp. 22-36).

Kent and Taylor, have applied dialogue to public relations, drawing on the philosophy of the religious existentialist Martin Buber (Bentley, 2012). In contrast, the fourth model has similar effects, which the neutral observer describes as beneficial to both parties, organizations, and groups. Organizations that use the same two-way public relations approach use bargaining, negotiation, and dispute resolution strategies to bring about coexistence-based changes in the thoughts, attitudes (Beverly, 2013), and behaviors of their organizations and target groups.

Many organizations occasionally use disproportionate two-way models; But the dominant model has rarely been used. In addition, organizations often use the two-way model of homogeneity alongside the two-way model of heterogeneity, refusing to accept that if communication is done under the guise of public relations, it should not be persuasive and deceptive (Patel et al., 2005; Beverly, 2013; Bhutan \& Hazleton, 2008: pp. 27-29).

Public relations is only the instrument through which the organization accomplishes its goals so media relations, and information subsidy are central areas of practice (Patel et al., 2005; Taylor \& Botan, n.d.). It is clear that the symmetric reciprocal model is the most responsible and intellectual type of 
communication (Patel et al., 2005; Van Heerden, 2004). We associate it with the form of public relations if it is modern and comprehensive. However, other models should not be considered as erroneous and disproportionate forms of communication and should not be rejected (Bentley, 2012; Ng, 2003). We consider them only inadequate. As we will see, they are still part of the common method of PR today, and we often take advantage of their possibilities under the umbrella of symmetrical reciprocal communication (Beverly, 2013; Cohen, 2008: pp. 13-14).

The first four models were introduced in 1984 by Grunig Hunt; but they later found that these four models did not have the capacity to adapt to all public relations programs and actions, so in 1992 they introduced models for the public relations industry (Beverly, 2013). The main features of each of the mentioned models are in Table 1.

Another model is the public relations industry, which emphasizes the effective use of communication techniques in order to promote the organization and emphasize the use of guided tactics in public relations. This model is a combination of the advertising/press agency model and the public information model, and Grunig has made up for the lack of information to the mass media (other than the press) (Patel et al., 2005; Ayman, Kaya, \& Kuruç. 2020). In such a way

Table 1. Comparison table of the main models of public relations based on Grunig and Hunt studies (Monib, 2017: p. 66).

\begin{tabular}{|c|c|c|c|c|}
\hline \multirow[b]{2}{*}{ Description } & \multicolumn{4}{|c|}{ Models } \\
\hline & Two Way equal & $\begin{array}{l}\text { Two Way } \\
\text { Unequal }\end{array}$ & $\begin{array}{c}\text { Public } \\
\text { Information }\end{array}$ & $\begin{array}{c}\text { Advertising/Press } \\
\text { Agency }\end{array}$ \\
\hline Goal & Understanding & $\begin{array}{l}\text { Scientific } \\
\text { persuasion }\end{array}$ & $\begin{array}{c}\text { Release } \\
\text { Information }\end{array}$ & Propaganda \\
\hline $\begin{array}{c}\text { Nature of } \\
\text { Communication }\end{array}$ & $\begin{array}{c}\text { Two-way, } \\
\text { balanced effects }\end{array}$ & $\begin{array}{l}\text { Two-way, } \\
\text { unbalanced } \\
\text { effects }\end{array}$ & $\begin{array}{l}\text { One-way, the } \\
\text { truth is important }\end{array}$ & $\begin{array}{l}\text { One Way, } \\
\text { complete truth } \\
\text { is not necessary }\end{array}$ \\
\hline $\begin{array}{l}\text { Nature of } \\
\text { Research }\end{array}$ & $\begin{array}{l}\text { Developmental; } \\
\text { Assessment of } \\
\text { comprehension }\end{array}$ & $\begin{array}{c}\text { Developmental; } \\
\text { Evaluating } \\
\text { attitudes }\end{array}$ & $\begin{array}{l}\text { Insignificant, mere } \\
\text { readability of texts } \\
\text { and attention to the } \\
\text { number of readers }\end{array}$ & $\begin{array}{l}\text { Less important, } \\
\text { just for Statistic }\end{array}$ \\
\hline $\begin{array}{c}\text { Communication } \\
\text { Model }\end{array}$ & Group-Group & Sender-Receiver & Sender-Receiver & Sender-Receiver \\
\hline $\begin{array}{l}\text { Prominent } \\
\text { Persons }\end{array}$ & $\begin{array}{l}\text { Bernice, coaches } \\
\text { and career leaders }\end{array}$ & Edward Bernice & EV Lee & P. B. Barunom \\
\hline Practical areas & $\begin{array}{l}\text { Regulated trade } \\
\text { and industry } \\
\text { and engagements }\end{array}$ & $\begin{array}{l}\text { Competitive } \\
\text { trade } \\
\text { and industry, } \\
\text { engagements }\end{array}$ & $\begin{array}{l}\text { Government } \\
\text { and non-profit } \\
\text { associations, } \\
\text { trade and industry }\end{array}$ & $\begin{array}{l}\text { Sports, theater } \\
\text { and production } \\
\text { promotion }\end{array}$ \\
\hline $\begin{array}{l}\text { Percentage of use } \\
\text { in organizations }\end{array}$ & $15 \%$ & $20 \%$ & $50 \%$ & $15 \%$ \\
\hline
\end{tabular}


that not only the press does not function and inform, and in this mission, the role of other media is also highlighted; On the other hand, not only the media but also public relations are considered as information institutions and do not engage in press activities.

The professional public relations model, public and organizational public relations are considered and attention is paid to issues such as the strategic role of public relations in guiding the organization's relations with social groups to limit the organization's self-centeredness (Ng, 2003). The success of social groups is emphasized along with solving the problems of the organization with them and the potential of public relations in the strategic policies of the organization. In fact, this model has a special aspect to conflict management (solving organizational problems with groups) and persuasion management (achieving success of social groups) through negotiation.

The two-way model was introduced in 1995 by Dozier and Broon (1995). In this model, by emphasizing the role of public relations in managing conflict and resolving disputes between organizations and social groups to overcome problems, five specific tactics to achieve the goal are proposed (Patel et al., 2005). In describing the two-way model, Dozier uses the "game" theory and the win-lose method. After stating the features of this model, in describing the five tactics of the game, it should be said that there is conflict and difference in the "competition" tactic (Patel et al., 2005; Ayman, Kaya, \& Kuruç. 2020).

Hybrid Model in 1996, introduced a hybrid model that added two more tactics to the previous five tactics. On the positive side, even if the opposing group insists on conflict, the organization seeks to reach a mutual benefit agreement. Unlike the tactic of agreement with the other side, in a useful and constructive tactic, it is on both sides.

The new symmetric model is composed of two-way and hybrid models that are similar to two-way activities. This model is based on "Mirofi" views, which use symmetric and asymmetric tactics. Criticizing hybrid designs and models, he believes that organizations continue to pursue their own profits while anticipating the reactions of the recipients, and that the organization's profits still have the first priority (Patel et al., 2005; Ayman, Kaya, \& Kuruç, 2020; Kazempour, Ashrafi Rizi, \& Abdullahi, 2013: p. 63).

\section{Theoretical Framework}

Public relations theory shares this organizing framework and is part of an organization's adaptive system. Within systems, there are various levels of adaptation, which are influenced by factors such as organizational resources, environmental predictability, and organizational management styles (Patel et al., 2005). According to the records and models expressed above from public relations and the views of experts in this field, public relations as a channel of communication inside and outside the organization and an area that creates a lot of added communication value; Introduce and consider indicators such as facilitation, interac- 
tion and responsiveness to desirable public relations. It is considered desirable in general. Accordingly, the conceptual model for the desired uncle relationships of public organizations can be presented in four general indicators: interaction or symmetry of public relations, use of new tools and technologies, management and, value Orbital.

The framework is a combination of science, experience, expertise, art and tact in recognizing the organization and communication tools in order to persuade public opinion, and this unit is a consulting and management system that plays a valuable role in policy-making and guidance. And the demands of the people and the audience of the organization are in the priority of its processes. This model has performance of public relations as a big umbrella business with many sub-categories. These subdivisions are often independent units in an organization, sometimes reporting to public relations and sometimes reporting to other organizational units such as legal resources, marketing, or human resources. Learning the sub-factors and glossary of terms related to this performance is crucial to understanding how to manage integrated and effective public relations performance. In the following sub-categories, we will discuss in more detail in the continuation of this volume.

\section{Methodology}

This research is exploratory in nature and practical in type. The method used in this research is a combination. In the qualitative method of research, semi-structured interviews were conducted with 15 elites and experts in the field of communication based on non-probabilistic sampling method of judgmental and purposeful type and the desired public relations indicators of Afghanistan Public Administration were obtained. And in a small part of this research, a number of experts, experts and employees of the press and public relations department of government organizations were selected as the statistical population. A small sample in this study from among employees, professors and experts in the field of public relations using Morgan table, 66 people were selected as a sample population, of which: 34 employees, 16 experts and 16 professors by quota. The sampling method was considered quantitative, probabilistic and relative stratified sampling method.

In this research, quantitative data analysis based on descriptive and inferential methods was used. The researcher first analyzed and described each of the research indicators in the form of univariate analysis in the form of frequency table and then in order to evaluate and present the desired public relations model, confirmatory factor analysis was used.

The sampling method was considered quantitative, probabilistic and relative stratified sampling method. To validate the interview questions and the questionnaire, while referring to the standard questionnaire, 5 university professors and public relations experts were consulted. Also, for the reliability of the questionnaire, Cronbach's alpha coefficient was selected, the size of which varies be- 
tween $(0-1)$ and the acceptable reliability coefficient in research is slightly higher than (0.7). Cronbach's alpha coefficient for each variable and the whole questionnaire is as follows (Table 2).

In this research, quantitative data analysis based on descriptive and inferential methods was used. The researcher first analysed and described each of the research indicators in the form of univariate analysis in the form of frequency table and then in order to evaluate and present the desired public relations model, confirmatory factor analysis was used.

\section{Findings}

The research findings are divided into two sections: The first category is the qualitative findings obtained from the interviews of 15 elites and experts, employees and professors in the field of public relations. Finally, the second category is a small number of findings based on a questionnaire distributed to 66 participants.

\subsection{Qualitative Findings}

The content analysis method and the network analysis method were used to analyze the interviews conducted in this research. In general, qualitative findings show that comprehensive, organized themes as well as the basic themes and characteristics of desirable public relations can be expressed as follows: social responsibility, moderation, democracy, merit Sovereignty, good reputation, fidelity and confidentiality, rationality, decision-making ability, planning ability, power of action and action, accountability, professional ethics, work ethic, job satisfaction, punctuality, duty Cognition, hard work, honesty, communication, and coordination, ability to write correspondence and long writing, ability and skill in resource management, audience knowledge, ability to speak, write, read, listen, negotiate And persuasion, creativity and innovation, new tools and technologies, speed and accuracy, two-way communication, interaction, dynamics and critical thinking, attractiveness, simplicity, ability to coherence, uncensored, intercession in affairs, ability to persuade, art of establishment Intra-organizational

Table 2. Cronbach's alpha coefficient for each of the research variables and questionnaire.

\begin{tabular}{ccc}
\hline Variables & No. of Questions & Cronbach's Alpha Coefficient \\
\hline Optimal public relations (general index) & 8 & 0.810 \\
Interactive & 8 & 0.841 \\
Instrumental and technological & 18 & 0.865 \\
Managerial & 21 & 0.885 \\
Value & 17 & 0.889 \\
Number of questionnaires & 72 & 0.943 \\
\hline
\end{tabular}


and extra-organizational communication, communication with the media, public relations, attention to civil and quasi-civil institutions, and finally the necessity of two-way public relations.

To analyze the interviews, content analysis was used and among different content methods, the content network method was used. To achieve the network of themes, the following steps were performed: Discover the main themes or basic concepts; Discover organized themes; Discover all-encompassing themes. After completing these steps, the resulting themes were drawn as web maps. Inclusive themes are at the heart of the themes network; organized themes are the interface between all-inclusive themes and the basic themes of the network. Basic themes indicate an important point in the text and by combining them, an organized theme is created.

The number of themes obtained from the interviews conducted in this study shows that, in general, the basic themes of desirable public relations of Afghan public organizations derived from qualitative data in the four sections are as follows:

Value orientation: comprehensiveness, As mentis Interactive public relations: the power of campaigning and networking, the art of communicating with the audience, communicating effectively with other institutions, communicating with the three forces, the necessity of external communication, reciprocity, the desire to exchange information to Instead of information exchange, continuous communication with the media; Increasing public relations, paying attention to civic institutions and in the field of intra-organizational communication; Attracting organized participation within, the art of establishing communication with employees, attention to democracy in the organization, effective communication with internal employees, the necessity of interaction and cooperation within the organization.

New tools and technologies: Internet, e-newsletter or e-magazine, official corporate blog, e-mail, e-brochure, paperless office system, social networks (Facebook, Twitter and YouTube), augmented messaging services, messaging services Multimedia messaging, Bluetooth, podcast, podcast, videoconferencing or teleconferencing, content management and gatekeeping, web conferencing, media communication, online newsroom.

In Table 3, favorable public relations of Afghan government organizations based on interviews with experts, thinkers, professors and staff of the public relations department of government organizations, on four general themes of management, interaction, value and There were 17 themes in the field of management, 16 themes in the field of public relations interaction, 21 themes in the field of value, and 18 themes in the field of tools and technology. After receiving and extracting general and sub-themes as well as basic themes related to desirable public relations, the researcher drew the desired model of public organizations in Afghanistan as follows (Figure 1).

According to the topics related to the above chart, it was concluded that the 


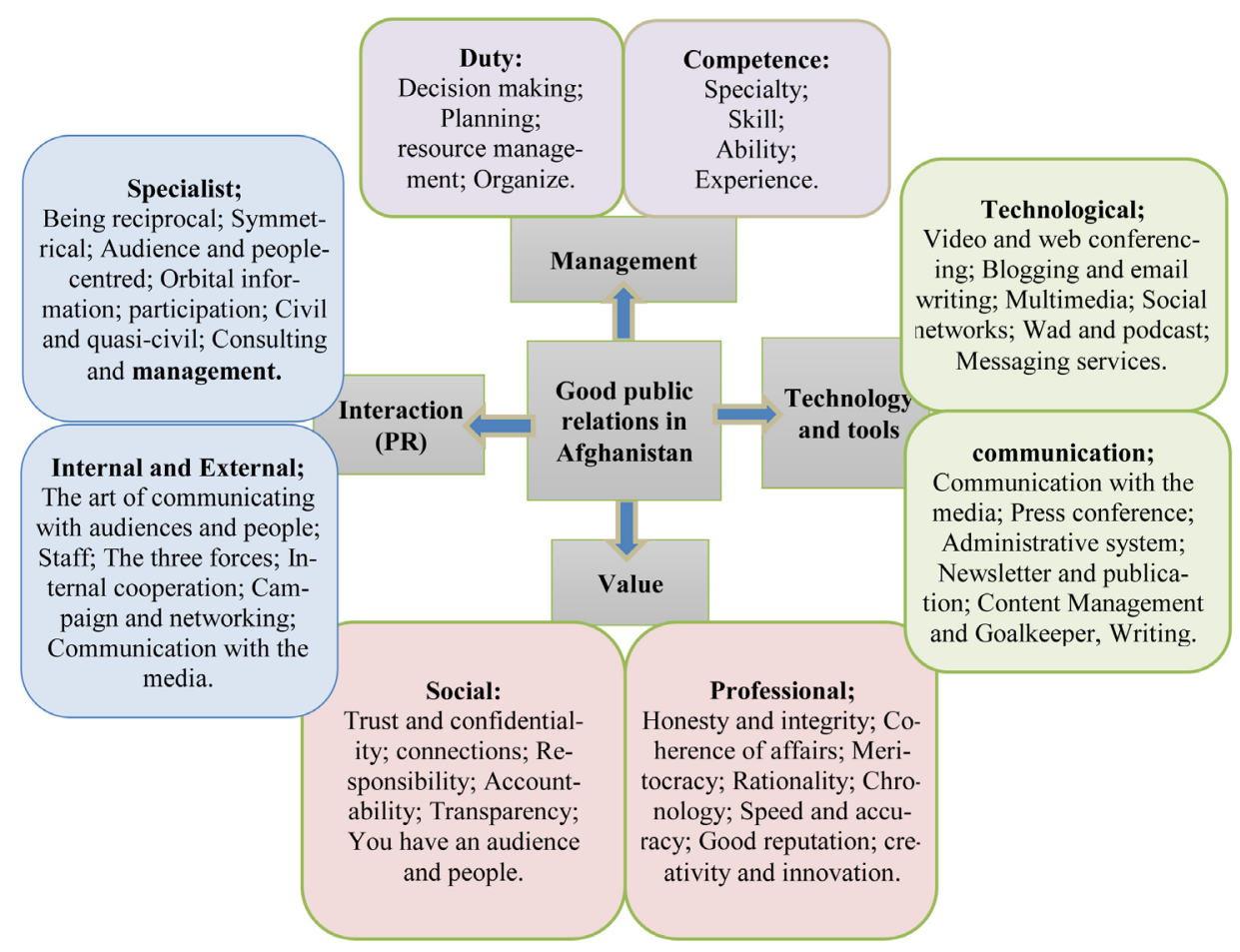

Figure 1. Proposed model of public relations.

Table 3. Favorable public relations model in the public sector.

\begin{tabular}{|c|c|c|c|c|}
\hline The main indicators & Management and ability & Orbital value & Technology and tools & $\mathrm{PR}$ interaction \\
\hline $\begin{array}{l}\text { Options selected } \\
\text { by the interviewees }\end{array}$ & $\begin{array}{l}\text { Contact management; } \\
\text { content management; } \\
\text { Ability to plan; } \\
\text { Decision making; } \\
\text { Coordination; } \\
\text { connections; } \\
\text { Administrative } \\
\text { correspondence and } \\
\text { essay writing; } \\
\text { Organizational resource } \\
\text { management; } \\
\text { Organizational resource } \\
\text { mobilization; } \\
\text { Speaking skills; } \\
\text { Active listening; } \\
\text { Critical Thinking; } \\
\text { Comprehension; } \\
\text { Negotiation; } \\
\text { Persuasion and writing; } \\
\text { Commitment to the } \\
\text { organization; } \\
\text { Electronic management. }\end{array}$ & $\begin{array}{l}\text { Simplicity and } \\
\text { comprehensibility; } \\
\text { Coherence; } \\
\text { creativity and } \\
\text { innovation; } \\
\text { Charm and allure; } \\
\text { Affection; } \\
\text { Moderation; } \\
\text { Reasoning and } \\
\text { thinking; } \\
\text { You have people; } \\
\text { Social responsibility; } \\
\text { Conscientiousness; } \\
\text { Ethics; } \\
\text { Trust and } \\
\text { confidentiality; } \\
\text { Being polite; } \\
\text { Good reputation; } \\
\text { Meritocracy; } \\
\text { Positivism; } \\
\text { satisfaction; } \\
\text { Chronology; } \\
\text { Orbital information; } \\
\text { Conscientiousness; } \\
\text { Honesty and accuracy. }\end{array}$ & $\begin{array}{l}\text { Internet; } \\
\text { E-newsletter or } \\
\text { electronic magazine; } \\
\text { Official organizational } \\
\text { blog; } \\
\text { email; } \\
\text { Electronic brochure; } \\
\text { Paperless office system; } \\
\text { Social networks } \\
\text { (Facebook, Twitter } \\
\text { and YouTube); } \\
\text { Added messaging } \\
\text { services; } \\
\text { Messaging services; } \\
\text { Multimedia; } \\
\text { Bluetooth; } \\
\text { podcast; } \\
\text { Videoconferencing, } \\
\text { teleconferencing and } \\
\text { web conferencing; } \\
\text { Content Management } \\
\text { and Goalkeeper; } \\
\text { Communication with } \\
\text { the media; } \\
\text { Online newsroom. }\end{array}$ & $\begin{array}{l}\text { The power of campaigning and } \\
\text { networking; } \\
\text { The art of communicating with } \\
\text { audiences; } \\
\text { Establish effective communication } \\
\text { with other institutions; } \\
\text { Communicating with the three } \\
\text { forces; } \\
\text { Requirement of external } \\
\text { communication; } \\
\text { Two-way public relations; } \\
\text { The tendency to exchange } \\
\text { information rather than } \\
\text { exchange information; } \\
\text { Continuous communication with } \\
\text { the media; } \\
\text { Increase public relations; } \\
\text { Attention to civic institutions; } \\
\text { Attracting organized participation } \\
\text { within; } \\
\text { The art of communicating with } \\
\text { employees; } \\
\text { Attention to democracy in the } \\
\text { organization; } \\
\text { Stable effective communication } \\
\text { with employees; } \\
\text { Necessity of interaction; } \\
\text { Indra-organizational cooperation. }\end{array}$ \\
\hline
\end{tabular}


desired public relations model of public organizations in Afghanistan is public relations that is appropriate in public and non-governmental organizations in the internal and external organizational departments. Among the important points in this model, qualified, specialized, elite, skilled, managerial and committed to the values that govern society and the profession seems to be mandatory. Organizational commitment is also one of the other important indicators that the employee and the manager of public relations are desirable in providing information system communication (information retrieval, information measurement and information and information archive), accountability to the community, transparency. In affairs, and have the skills to use new tools and technologies.

\subsection{Quantitative Findings}

In fact, the questions addressed in the quantitative section are an inference from the theoretical foundations and qualitative findings of the conceptual model of public relations desired by Afghan public organizations. Good public relations of public organizations in Afghanistan is formed in four general categories of management, tools and technology, value and interaction of public relations and has been measured and tested with a total of 72 questions in the distribution of central statistics and the distribution of good public relations of the organization. Afghanistan's public relations among public relations staff, university professors, and public relations and communications experts is shown in Table 4.

In the inferential analysis of this research, in order to present the desired public relations model of public organizations in Afghanistan, Amos software (Analysis of Moment Structure) 20 was used. In the first step, the model was presented based on the general index with observable variables (managerial, instrumental and technological, value, interactive), which finally shows the desired model based on the following standard coefficients (Figure 2).

Based on the chart above, the proposed public relations model bears a similar resemblance to the conceptual research model based on the researcher interview. In addition, the model of measuring the good public relations of public organizations in Afghanistan based on standard coefficients and general indicators of

Table 4. Variables of quantitative method.

\begin{tabular}{cccccccc}
\hline Model indicators & Average & $\begin{array}{c}\text { Crossed } \\
\text { line }\end{array}$ & $\begin{array}{c}\text { amount of } \\
\text { deviation }\end{array}$ & Minimum & Maximum & Total \\
\hline $\begin{array}{c}\text { Optimal public relations } \\
\text { (general index) }\end{array}$ & $456 / 145$ & 435 & $149 / 351$ & 181 & 724 & 62 \\
$\quad$ Interactive & $52 / 333$ & 48 & $13 / 502$ & 26 & 79 & 66 \\
$\begin{array}{c}\text { Instrumental } \\
\text { and technological }\end{array}$ & $62 / 257$ & 66 & $18 / 207$ & 30 & 110 & 66 \\
$\quad \begin{array}{c}\text { Managerial } \\
\text { Value }\end{array}$ & $249 / 274$ & 231 & $92 / 747$ & 82 & 385 & 62 \\
No. of Observation & $49 / 545$ & 90 & $32 / 904$ & 33 & 150 & 66 \\
\hline
\end{tabular}




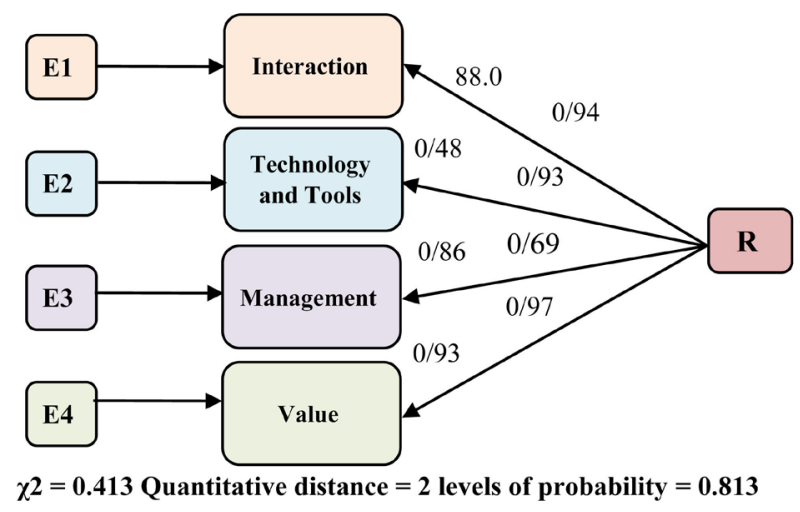

Figure 2. Diagram of a model for measuring the desired public relations of afghan public organizations based on standard coefficients.

the conceptual model have a high degree of correlation with each other. The value of this correlation is based on standard coefficients for the value index equal to 966 , for the interaction index equal to 940 , for the instrumental and technology index equal to 693 and finally for the management index equal to 925. Interestingly, the highest correlation is seen in the value index.

\section{Conclusion}

This study was conducted with the aim of developing an appropriate framework and model for public relations of public organizations in Afghanistan with a combined research approach (qualitative and quantitative). Interviews and questionnaires were used to collect information. The researcher first presented the conceptual model of the research using the interview method and prepared and tested the four indicators (value, interactive, technological and instrumental and managerial) in a questionnaire.

Based on the results obtained from the qualitative method of this research, the proposed model of public relations is desirable for Afghan public organizations in various fields, especially public organizations in the areas of internal and external communication. To perform this model better and more effectively, public organizations must have specialized, experienced and efficient human resources. To manage the public relations department, employees and managers of the public relations department should be acquainted with the components of competence and value as well as organizational commitment. Two-way Symmetric public relations include the indicators such as activities, accountability, transparency, moderation, confidentiality and trustworthiness, good reputation, creativity and innovation, and finally self-confidence of an organization to achieve organizational goals through two-way communication. The public is favored by Afghan public organizations. Another important factor that was considered in this study and the result obtained, is the creation of an information-based system. This system makes the public relations department both informative and informative, and finally by measuring, processing and archiving information, public relations can perform its better activities and effectiveness of 
the performance of the public organizations to reach the public.

Also, the results are obtained that the overall public relations like managerial, value, interactive, and instrumental, and technological options of the proposed model of public relations desired at a high level and it is relatively desirable of public organizations in Afghanistan. Of course, the results were almost identical in the views of professors, staff and experts. However, the results of quantitative findings also show that there was a value index at a high level of acceptance.

In general, the conceptual model obtained based on the collection of information from the interviewees is in fact similar to the studies obtained from the theoretical foundations of the research and other models and theories of public relations. Among the four models of Grunig and Hunt, the two-way model is two-way symmetric. The results of this study also show that the favorable public relations model of public organizations in Afghanistan is two-way, interactive and one of the models of excellence based on the study. One of the different results obtained in this study is the value orientation of the activities of the public relations sector in the country, which is due to the value and idealism of society.

\section{Recommendations}

Based on the results of the research findings, the researcher offers the following practical suggestions for the public relations departments of public organizations:

Employing employees and managers in the public relations department who are both value-oriented and have sufficient expertise, skills and competence.

In the second priority, the researcher suggests that managers of public relations in the field of management such as decision making, strategic planning, implementation, monitoring and consulting with senior management and subordinates of public relations to play an appropriate role.

Based on the obtained results, it is suggested by the researcher that the employees and managers of the public relations department have sufficient proficiency, skills and ability to use new tools and technologies in order to carry out their mission. Among these, the researcher's specific suggestion in the field of learning and teaching electronic skills and electronic public relations.

One of the researcher's suggestions according to the results of this research is to strengthen the value foundations (both organizational and community) that employees and public relations managers can improve this practice as a model for public organizations.

Public relations work is not just about creating, providing, expanding and consolidating external communications; rather, the researcher suggests that the public relations department should try to provide and strengthen communications within the organization as much as it does in the field of informing and providing external communications.

Based on the results of the present study, the researcher suggests that the public relations department in full coordination with the strategic department of public organizations to create and strengthen an information-oriented system. 
The results of this study also suggest that the public relations department to establish studies and research departments to provide appropriate contexts for measuring public opinion regarding the mission of public organizations and the feedback of the public and the audience to Will be achieved.

Finally, the latest proposal of the present study is that in order to strengthen the activities and missions of the public relations department, it is necessary to create a favourable monitoring system at various stages.

\section{Conflicts of Interest}

The authors declare no conflicts of interest regarding the publication of this paper.

\section{References}

Ayman, U., Kaya, A. K., \& Kuruç, Ü. K. (2020). The Impact of Digital Communication and PR Models on the Sustainability of Higher Education during Crises. Sustainability, 12, 8295. https://doi.org/10.3390/su12208295

Bahramian, S. (2011). Iranian Public Relations Model. http://www.jccs.ir/article 57573 1aa2af90e3fd452a8cc1ccc79ce6a13e.pdf

Bentley, J. M. (2012). Applying Dialogic Public Relations Theory to Public Relations Education. Teaching Journalism and Mass Communication, 2, 1-11. https://aejmc.us/wp-content/uploads/sites/9/2012/06/tjmc-s12-res-bentley.pdf

Beverly, J. A. (2013). Public Relations Models and Dialogic Communication in the Twitterverse: An Analysis of How Colleges and Universities Are Engaging Their Publics Through Twitter. Dissertations 159, Hattiesburg, MS: The University of Southern Mississippi. https://aquila.usm.edu/dissertations/159 https://aquila.usm.edu/cgi/viewcontent.cgi? article $=1180 \&$ context $=$ dissertations

Bhutan, C., \& Hazleton, V. (2008). Public Relations Theories (2nd ed.). Tehran: Office of Media Studies and Development.

Cabot, M. (2012). Introduction to Public Relations. San Jose, CA: San Jose State University, AJEEP. https://www.sjsu.edu/ajeep/docs/IntroToPR.pdf

Cohen, P. M. (2008). Public Relations Textbook (Translation, S. M. Khamoushi, \& M. S. Ghazi, 1st ed., pp. 13-14). Tehran: Office of Media Studies and Development.

Dozier, D., \& Broon, G. M. (1995). Evolution of the Manager Role in Public Relations Practice. Journal of Public Relations Research, 7, 3-26. https://doi.org/10.1207/s1532754xjprr0701 02

Grunig, J. E. (2006). Research in Public Relations: Current Status and New Directions. Anàlisi, 34, 49-65. https://core.ac.uk/download/pdf/38977756.pdf

Grunig, J. E. (n.d.). Excellence Theory in Public Relations. College Park, MD: University of Maryland.

https://kdpaine.blogs.com/files/encylopedia-of-communication-9781405131995 chapt er 399.pdf

Grunig, L. A. (1994). A Positive Relativist Philosophy of Public Relations. In W. Armbrecht, \& U. Zabel (Eds.), Normative Aspekte der Public Relations (pp. 13-34). Wiesbaden: VS Verlag für Sozialwissenschaften. https://doi.org/10.1007/978-3-322-97043-5 1

Hobbs, M., \& Mann, A. (n.d.). Public Relations: Strategies and Tactics. 
http://lib.oup.com.au/he/media journalism/Chalkley CDMEL2e Online.pdf

Kazempour, Z., Ashrafi Rizi, H., \& Abdollahi, A. S. (2013). Introduction to Public Relations (1st ed.). Tehran: Payame Noor University.

Mackey, S. (2003). Changing Vistas in Public Relations Theory. PRism, 1, 1-9. https://www.prismjournal.org/uploads/1/2/5/6/125661607/v1-no1-a1.pdf

Maina, N., \& Mberia, H. (2014). Application of Public Relations Theories in the Practice of Public Relations in National Government Ministries. International Journal of Education and Research, 2, 341-354. https://www.ijern.com/journal/April-2014/30.pdf

Monib, F. A. (2017). Public Relations Strategic Management. Berlin: Lanbert Publication.

Ng, E. (2003). Public Relations Theory and Processes. Thesis. http://www.edvencomm.net/gsc2410.pdf

Patel, A. M., Xavier, R. J., \& Broom, G. (2005). Toward a Model of Organizational Legitimacy in Public Relations Theory and Practice. Proceedings International Communication Association Conference, New York, 1-22. https://eprints.qut.edu.au/10132/1/10132.pdf

Rex, C. (2015). Upgrading Grunig \& Hunt: A Reconceptualization of Grunig \& Hunt's Public Relations Models from a CCO Perspective. Master Thesis, Frederiksberg: Copenhagen Business School. https://research-api.cbs.dk/ws/portalfiles/portal/58510874/charlotte rex.pdf

Rhee, Y. (2004). The Employee-Public-Organization Chain in Relationship Management: A Case Study of a Government Organization. Unpublished Doctoral Dissertation, College Park, MD: University of Maryland.

https://www.csus.edu/indiv/r/rheey/rhee an\%20overview.pdf

Sefidi, H. (2015). Fundamentals of the Iranian Islamic Model of Public Relations. Journal of Culture-Communication, 18, 39.

Shukri Khaneghah, H. (2015). Smart Public Relations. Tehran: Nutrition and Health Publications.

Soltanifar, M., \& Noorabadi, M. (2015). Smart Public Relations. Tehran: Nutrition and Health Publications.

Taylor, M., \& Botan, C. H. (n.d.). Global Public Relations: Application of a Correlational Approach (pp. 485-492). IPRRC.

http://195.130.87.21:8080/dspace/bitstream/123456789/742/1/Global\%20Public\%20Rel ations-Application \%20of\%20a\%20Cocreational\%20Approach.pdf

Van Heerden, G. (2004). The Practice of Public Relations in Africa: A Descriptive Study. Pretoria: University of Pretoria.

https://repository.up.ac.za/bitstream/handle/2263/28138/Complete.pdf?sequence $=11$ 